\title{
Range structure, microhabitat use, and activity patterns of the saxicolous lizard Tropidurus torquatus (Tropiduridae) on a rock outcrop in Minas Gerais, Brazil
}

\author{
Organización espacial, utilización de los microhábitats y padrones de actividad \\ del lagarto saxícola Tropidurus torquatus (Tropiduridae) en un afloramiento rocoso \\ en Minas Gerais, Brasil
}

LEONARDO B. RIBEIRO ${ }^{1,3, *}$, BERNADETE M. SOUSA ${ }^{1,2} \&$ SAMUEL C. GOMIDES $^{1}$

\begin{abstract}
${ }^{1}$ Programa de Pós-Graduação em Ciências Biológicas - Comportamento e Biologia Animal, Instituto de Ciências Biológicas, Universidade Federal de Juiz de Fora, Campus Universitário, Martelos, 36036-900, Juiz de Fora, MG, Brazil

${ }^{2}$ Departamento de Zoologia, Instituto de Ciências Biológicas, Universidade Federal de Juiz de Fora, Campus Universitário, Martelos, 36036-900, Juiz de Fora, MG, Brazil

${ }^{3}$ Current Address: Programa de Pós-Graduação em Psicobiologia, Universidade Federal do Rio Grande do Norte, Centro de Biociências, Campus Universitário, Lagoa Nova, 59078-970, Natal, RN, Brazil

*Corresponding author: ribeiro.lb@gmail.com
\end{abstract}

\begin{abstract}
Although Tropidurus is a widely distributed lizard genus in South America and the Galapagos Islands, studies on space use and spatial distribution are scarce. We studied the home range structure of the saxicolous lizard Tropidurus torquatus based on the inland population of a rock outcrop in Minas Gerais State, southeastern Brazil. Lizards were individually marked and observed during reproductive and non-reproductive seasons. Using the minimum convex polygon method, we found that average total range size of males during the reproductive season was larger than that of females, and that both had similar total range sizes in the nonreproductive season. The harmonic mean method showed that males have a larger home range size than that of females during both seasons. As expected for a polygynous species, the average number of males whose total ranges overlapped those of females tended to be higher in the reproductive season than in the nonreproductive season. Intrasexually, the number of females whose total ranges were associated with those of other females was also higher in the reproductive season than in the non-reproductive season. For males, this number remained low in both seasons, suggesting that males use more exclusive areas, whereas the smaller total ranges of females apparently sustain a higher density of individuals during the reproductive season. Frequency of microhabitat use in relation to vegetation increased in the non-reproductive season and the activity patterns of lizards shifted from bimodal in the reproductive season (rainy period) to unimodal in the non-reproductive season (dry period). Thus, the range structure, microhabitat use, and activity patterns of the T. torquatus observed here were all influenced by the time frame affecting their spatial ecology.
\end{abstract}

Key words: activity times, habitat use, home range, total range, Tropidurus.

\section{RESUMEN}

Aunque Tropidurus es un género de lagarto extensamente distribuido en Sudamérica y en las islas Galápagos, son escasos los estudios sobre uso del espacio y distribución espacial. En este trabajo se estudió la organización espacial del lagarto saxícola Tropidurus torquatus basado en la población interiorana de uno afloramiento rocoso en el estado de Minas Gerais, sudeste del Brasil. Los lagartos fueron individualmente marcados y observados durante las estaciones reproductiva y no reproductiva. Con el método del mínimo polígono convexo fue encontrado que el tamaño promedio del dominio vital de los machos durante la estación reproductiva fue más grande que el de las hembras y en la estación no reproductiva hembras y machos mantuvieron dominios vitales similares en el tamaño. El método de la media armónica mostró que el tamaño promedio del área de vida de machos fue mayor que el área de las hembras en ambas estaciones. Como esperado para una especie poligínica, el número medio de machos con dominios vitales sobrepuestos a los de las hembras tendió a ser más grande en la estación reproductiva. Intrasexualmente, el número de hembras con 
sus dominios vitales asociados a los de otras hembras también fue mayor en la estación reproductiva. Para los machos, este número permaneció bajo en ambas estaciones, lo que sugiere que los machos usan áreas más exclusivas, mientras los dominios vitales más pequeños de las hembras al parecer sostengan una mayor densidad de individuos durante la estación reproductiva. La frecuencia de uso de los microhábitats relacionados a la vegetación aumentó en la estación no reproductiva y el padrón de actividad de los lagartos cambió del bimodal en la estación reproductiva (período lluvioso) para unimodal en la no reproductiva (período seco). Así la organización espacial, la utilización de los microhábitats y los padrones de actividad de T. torquatus aquí observados fueron todos influenciados por el período de tiempo afectando la ecología espacial de los lagartos.

Palabras clave: área de vida, dominio vital, horarios de actividad, Tropidurus, utilización del hábitat.

\section{INTRODUCTION}

Spacial dispersion, microhabitat use and activity patterns are the important components of vertebrate ecology (Lott 1991). In a broader ecological context, home range, which is the space that individuals use to carry out their life cycles (Rose 1982), can reveal information about the spatial ecology, resource holding power, and social mating systems operating in a group (Brown \& Orians 1970, Loehle 1990). Indeed, animals are non-randomly distributed in space (Hodder et al. 1998), and some studies have shown that they respond to diversity in microhabitat resources by adopting selection strategies to increase their survivorship and opportunities for successful mating (Davies 1991, Lott 1991). Moreover, for many animals, activities such as basking, foraging, and searching for mates may be restricted to certain periods of the day or year (Lima \& Dill 1990).

Lizards are excellent model organisms for studies on space use because they often display wide variations in range size within and among species (Perry \& Garland 2002, Stone \& Baird 2002). Lizards may shift their range location and size in response to seasonal and climatic change, variations in habitat productivity, distribution or lizard density, and reproductive factors such as breeding season (Sheldahl \& Martins 2000, Haenel et al. 2003a, Wone \& Beauchamp 2003, Kerr \& Bull 2006). In some cases, the range size of lizards is affected by sex, where male home range sizes depend on the presence and dispersion of females, but for females, the selection of home ranges is independent of males and more dependent on reproductive sites (Van Sluys 1997, Frutos \& Belver 2007).

Microhabitat use by lizards can be influenced by biotic factors, such as intra/inter-specific competition (Schoener 1977, Núñez et al. 1989), predator avoidance (Vitt \& Carvalho 1995), as well as size and morphology of the individual (Vitt et al. 1997). On account of such factors, use of the microhabitat can be selective. It may have an indirect effect on thermoregulation and may also have an influence on the evolution of thermal preferences. Therefore, differences in the pattern of temporal activity, use of space, foraging pattern, eating habits, and bodytemperature relations for lizards are not independent of each other; on the contrary, they are complex interactions between biotic and abiotic factors (Radder et al. 2005). Indeed, most lizards exhibit high activity during discrete times of the day/year and the factors controlling such periodicity interact in a complex manner ( $\mathrm{Zug}$ et al. 2001). Further, activity patterns may be unimodal or bimodal depending on the species, or among different populations of the same species living in different climatic conditions and geographic locations (Hatano et al. 2001, Ribeiro et al. 2008).

The tropidurid lizard Tropidurus torquatus (Wied, 1820), typical of open areas, has a wide geographic range spanning from central Brazil to northern Argentina (Rodrigues 1987). In Brazil, the species has three distinct population groups: (i) an insular group in the Abrolhos archipelago (approximately $70 \mathrm{~km}$ off the southern coast of the state of Bahia), (ii) an inland group (occurring in Cerrados and open areas belonging to the Atlantic Forest Domain), and (iii) a coastal group (found in sand-dune habitats in the states of Rio de Janeiro, Espírito Santo and Bahia) (Rodrigues 1987). While important to understanding natural history, descriptive studies of spatial distribution are scarce for $T$. torquatus, mainly for the inland group. Here, we investigated the spatial habitat use patterns of an inland $T$. torquatus population to determine the average size of male and female $T$. torquatus ranges during 
different seasons of lizard activity. In addition, we analyzed how adult lizard ranges overlap within and between sexes. Finally, we investigated the microhabitats used by lizards and their activity patterns at different times of the year.

\section{METHODS}

\section{Study area}

This study was carried out in an area characterized by a quartzite rock outcrop, on the left bank of the River Peixe $\left(21^{\circ} 48^{\prime} 27.5^{\prime \prime} \mathrm{S}\right.$, 4335'31.7" W, datum: WGS 84; $697 \mathrm{~m}$ altitude) in the Toledos district, Juiz de Fora municipality, in the Zona da Mata region, southeastern Minas Gerais, Brazil. The study area (locally known as "Funil") is a rocky meadow enclave in the form of an isolated floristically-rich island established on a quartzite rock outcrop. It has a predominantly herbaceous-shrubby phytophysiognomy with under-developed trees growing between rock blocks. Floristic composition is mainly characterized by plants of the families Apocynaceae (Mandevilla tenuifolia), Asteraceae (Eremanthus erythropappus), Bromeliaceae (Dyckia sp.), Leguminosae (Clitoria sp.), Melastomataceae, Myrtaceae, and Velloziaceae (Vellozia sp.) (FRG Salimena, unpubl. data). The tropical climate in this region has two defined seasons: one hot and wet (October through April), the other cool and dry (May through September). Mean annual rainfall is about $1,536 \mathrm{~mm}$, and mean annual temperatures oscillate around $19.4{ }^{\circ} \mathrm{C}$. February is the hottest month, with a mean daily average temperature of $23.6{ }^{\circ} \mathrm{C}$. The coolest months are July and August, with a mean temperature of $15.8{ }^{\circ} \mathrm{C}$ (Plano Diretor/JF 2004).

\section{Collecting methods and observational study}

We delimited a $60 \mathrm{~m} \times 70 \mathrm{~m}$ grid encompassing an entire rock outcrop and about $10 \mathrm{~m}$ of the surrounding area (rock outcrop-soil interface). No other outcrops were found in the immediate area. Reference points were positioned at $5 \mathrm{~m}$ intervals in an X-Y coordinate system. The lizards were captured within this area, either by adhesive traps or by hand, from November
2004 through June 2005, during a four-day period every month. Lizards captured in traps were carefully removed from them using a paint-brush with vegetable oil, when necessary.

We marked the lizards with elastic bands (Ribeiro \& Sousa 2006), which were fitted to the lizard's neck for individual identification. The bands are made of silicone and were used in up to two color combinations to permit easy identification during the observation. Once marked, the specimens were released at the point of capture. Specimens were withdrawn from the study when the colored bands were lost or when we could no longer identify the lizard because the color had faded from their bands. However, recaptured specimens were fitted with new bands. The animals were also marked with nail-polish, which strongly adhered to the imbricated and keeled scales on the dorsal surface at the base of the lizards' tail. The polish was resistant to ecdysis, allowing us to differentiate between a lost band and a new, unmarked lizard.

One week after marking the lizards, over a 4-day period during each month, one observer systematically covered the whole study area between 08:00 and 17:00 $\mathrm{h}$, recording the marked specimens with the help of binoculars (Bushnell 7 x 35). These 4-day observation periods occurred at 30-day intervals. Each lizard location was marked with adhesive tape containing the date, number and time the animal was sighted. At the end of the observation period, the locations from that day were measured (to the nearest $1 \mathrm{~cm}$ ) in relation to the points of the $\mathrm{X}-\mathrm{Y}$ coordinate system to estimate lizard home range sizes.

Following Van Sluys (1997), we used different paths on each sampling day to reduce the chance of locating the same individual at the same site and time of day. To reduce possible disturbance effects arising from passing close to the lizards, we considered the first two positions for individuals sighted several times during the same day (Van Sluys 1997), the first in the morning and the first in the afternoon. For individuals sighted more than once only in the morning or only in the afternoon, we considered the first sighting in each period. We adopted this measure to ensure a balance among the observations made over the course of the animals' daily activities (De Solla et al. 1999). 
Size, body mass and sexual dimorphism

From each individual we obtained the following data: snout-vent length (SVL) - from tip of snout to anterior end of cloaca (to the nearest $0.1 \mathrm{~mm}$, with a manual caliper) and body mass (with a Pesola dynamometer, to the nearest $0.5 \mathrm{~g}$ ). The lizards were classified as adults according to the minimum maturity size (SVL $\geq 70 \mathrm{~mm}$ for adult males, and $\geq 65 \mathrm{~mm}$ for adult females) established by Wiederhecker et al. (2002). Adult males have colored patches ranging from yellow to yellow and black to solid black on the ventral part of the thighs and pre-cloacal flap (Pinto et al. 2005). Adult females and juveniles of both sexes lack these colored ventral patches.

\section{Home range estimation}

Given that home range size may differ between sexes and seasons (Rose 1982), the male and female areas were calculated during part of the reproductive season (RS, November 2004 through February 2005) and part of the nonreproductive season (NRS, March through June 2005). We estimated minimum convex polygons (MCPs) for lizard home ranges with $100 \%$ of the locations, which is equivalent to the total range, using a Home Range Analysis and Graphics Package (vers. 6.07.91, Niewiarowski PH \& AE Dunham, unpublished data; see Haenel et al. 2003b). We used MCP maps to estimate the relative size of male and female ranges, range location, and to identify the range overlap between males and females. We did not calculate juvenile home range sizes. In our study, the MCP area increased until the empirical curve reached an asymptote after eight sightings (Fig. 1). Thus, we only considered individuals with eight or more observations to calculate total range.

Animals generally use space disproportionately because they often live in a spatially heterogeneous environment within the boundaries of their range (Hodder et al. 1998). In this sense, in our study, home range (area intensively used by the animal; Linn \& Key 1996) was determined from the shortest mean distance between locations within range cores that were derived by the harmonic mean estimator (Dixon \& Chapman 1980), using Calhome - Home Range Analysis Program (freeware).
To use the harmonic mean method, we verified which percentages of lizard locations $(50,60,70,80,90$ and $100 \%)$ significantly represented the female and male home ranges and their respective sizes (in $\mathrm{m}^{2}$ ) in each season. By convention, $95 \%$ of the sightings are used to calculate home range (Dixon \& Chapman 1980). However, $95 \%$ would not provide conclusive evidence regarding the areas most used by the animals, given that this percentage is quite near to that used for total range $(100 \%)$. Thus, we identified the area intensively used by the lizards in contrast to the less used peripheral portion, when there was no difference between home range sizes as a function of the increased number of external sightings, which corresponded to between 50 and $100 \%$. Note that a minimum of eight sightings was required to calculate total range (Fig. 1). Therefore, the determination of home range sizes starting with $50 \%$ of the locations per lizard was equivalent to a minimum of four sightings.

\section{Microhabitat sampling}

Transects were also conducted monthly (from November 2004 to June 2005) during other three-day trips. One observer walked from 8:00 to $17: 00 \mathrm{~h}$ at hourly intervals along six welldemarcated trails measuring approximately $70 \mathrm{~m}$ long and spaced $10 \mathrm{~m}$ apart across the entire rocky outcrop habitat and its edges $(\sim 10 \mathrm{~m})$ in the focal area. Transects were walked in opposite directions to minimize the probability of repeatedly observing the same individual. However, some lizards may have been recorded more than once. We consider this procedure justified by the fact that time periods between observations at any given location exceeded one hour, and therefore, each observation represented an independent event (Vitt et al. 1996). Active lizards (marked or not) were observed on the transects in close proximity to the observer (at a distance of about $2 \mathrm{~m}$ ), who recorded the time of observation and microhabitat used at the moment of sighting into one of five categories: i) on rock (R); ii) on bare sand (BS, substrate resulting from rock fragmentation); iii) on sand covered with vegetation ( $\mathrm{SV}$, herbaceous-shrubby vegetation); iv) on tree trunks or branches (T); v) on bromeliad (B). We also measured air 
temperature $\left( \pm 0.1{ }^{\circ} \mathrm{C}\right)$ in the sun at a height of 2 $\mathrm{m}$ above ground level every hour, at the same site, using a thermohygrometer (Oregon Scientific model THG312).

\section{Statistical analyses}

Differences in average total range size between the sexes during each season, estimated by the minimum convex polygon method, were tested using the Mann-Whitney U test (Zar 1999). Kruskal-Wallis non-parametric analysis of variance with post-hoc Mann-Whitney U tests were used to analyze differences in average home range size among the six percentages of locations for both sexes during each season, estimated by the harmonic mean method. This technique allowed us to identify the representative female and male home range size in each season. Differences in average home range size between sexes during each season were also tested using the Mann-Whitney U test (Zar 1999). For the same females and males monitored during the entire study, Wilcoxon tests were used to analyze the change in their total and home range sizes between seasons. Spearman's correlation was used to test the relationship of both snout-vent length (SVL) and body mass to range size. Seasonal differences in microhabitat use were tested by the Chi-squared test. Seasonal differences in activity patterns were verified using the Kolmogorov-Smirnov test for two samples (Siegel 1975). Statistical calculations were performed using SPSS 13.0 (SPSS Inc. 2004). The significance level was 0.05 . Descriptive statistics are expressed in the text as mean $\pm \mathrm{SD}$.

\section{RESULTS}

\section{Gender and seasonal differences}

During the sampling period, 181 lizards were captured: 84 females, 62 males and 35 juveniles. For range size estimation (excluding juveniles), we considered 35 individuals (14 males and 21 females) in the reproductive

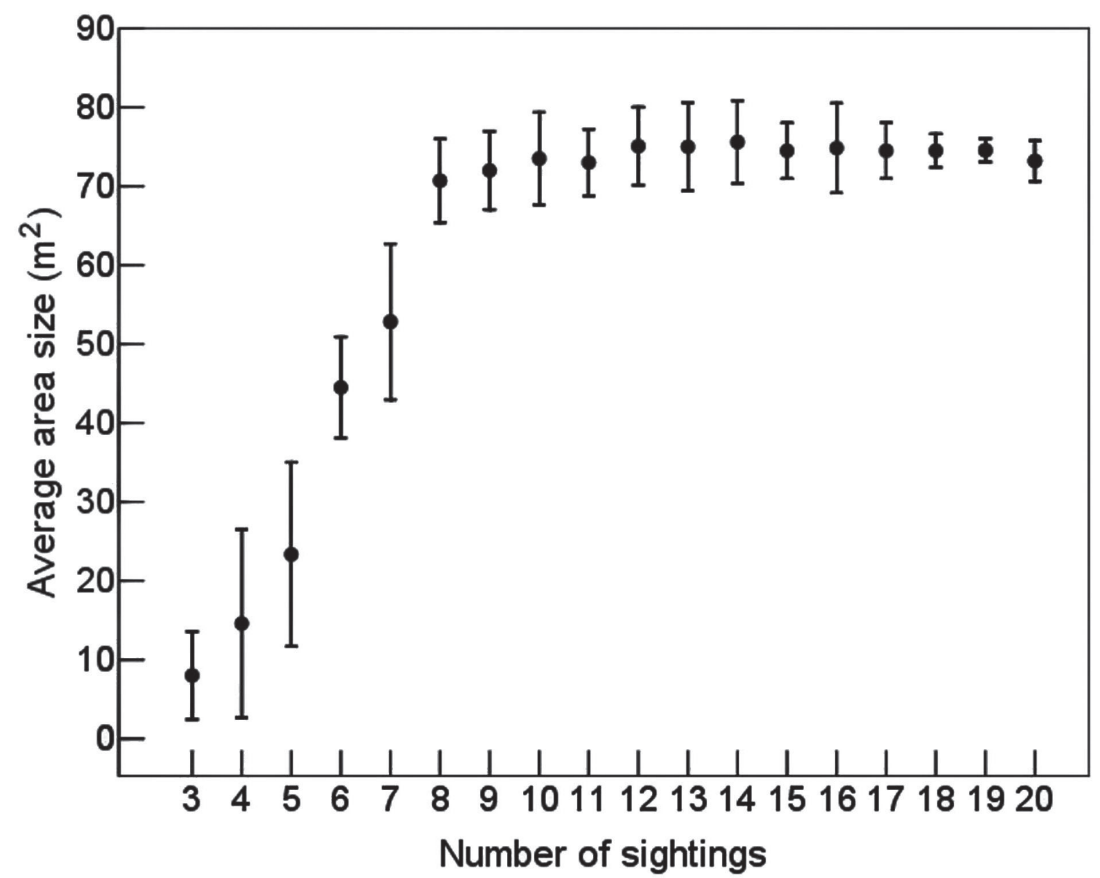

Fig. 1: Average MCP area ( $\pm 1 \mathrm{SD}$ ) versus number of sightings for Tropidurus torquatus on a rock outcrop in the state of Minas Gerais, southeastern Brazil. MCP area increases until the empirical curve reaches an asymptote after eight sightings.

Tamaño promedio del dominio vital $( \pm 1 \mathrm{DE})$ versus el número de ubicaciones para Tropidurus torquatus en un afloramiento rocoso en el estado de Minas Gerais, sudeste de Brasil. El área del mínimo polígono convexo aumenta hasta que la curva empírica alcanza una asíntota a partir de ocho ubicaciones. 
season and 36 (13 males and 23 females) in the non-reproductive season. Mean number of sightings per individual for each sex in both seasons was: RS, males: $12.07 \pm 1.38$ (range $=$ 10-14), females: $12.52 \pm 2.06$ (range $=8-16$ ); NRS, males: $13.84 \pm 3.23$ (range $=10-20)$, females: $13.65 \pm 2.96$ (range $=8-19$ ) .

Males have larger total range size than females (Mann-Whitney $\mathrm{U}$ test, $\mathrm{Z}=-3.21, \mathrm{P}=$ 0.039; Table 1) during the reproductive season, but during the non-reproductive season, females and males had similar total range sizes (Mann-Whitney U test, $\mathrm{Z}=-1.02, \mathrm{P}=0.307$; Table 1). Moreover, during the nonreproductive season, the total range size of both females (RS: $33.4 \pm 10.0 \mathrm{~m}^{2}$; NRS: $61.0 \pm 21.2$ $\mathrm{m}^{2} ; \mathrm{n}=8$; Wilcoxon test, $\mathrm{Z}=-2.10, \mathrm{P}=0.036$ ) and males (RS: $46.5 \pm 21.4 \mathrm{~m}^{2}$; NRS: $73.0 \pm$ $35.8 \mathrm{~m}^{2} ; \mathrm{n}=11$; Wilcoxon test, $\mathrm{Z}=-2.13, \mathrm{P}=$ 0.033 ) monitored during the eight months was larger than during the reproductive season.

The number of females associated with the total ranges of other females was larger during the reproductive season $(5.4 \pm 1.6)$ than during the non-reproductive season $(2.5 \pm 1.2$; MannWhitney $\mathrm{U}$ test, $\mathrm{n}_{1}=5, \mathrm{n}_{2}=4, \mathrm{Z}=1.00, \mathrm{P}=$ $0.025)$. There was no such difference for males (Mann-Whitney U test, $\mathrm{n}_{1}=2, \mathrm{n}_{2}=3, \mathrm{Z}=2.00$, $\mathrm{P}=0.543$ ), and in fact, intrasexual overlap remained low in both seasons for males (RS: $1.5 \pm 0.7$; NRS: $2.0 \pm 1.0)$. There was no difference in number of females included in the total ranges of males from the reproductive (3.5 $\pm 1.8)$ to the non-reproductive season $(2.0 \pm$ 1.0; Mann-Whitney U test, $\mathrm{n}_{1}=6, \mathrm{n}_{2}=3, \mathrm{Z}=$ $4.50, \mathrm{P}=0.239)$. There was no relation between the female and male body size or body mass and their total range size in both the reproductive $\left(\mathrm{SVL}_{\text {females }}: \mathrm{r}_{\mathrm{s}}=-0.43, \mathrm{n}=21, \mathrm{P}=\right.$ 0.052 / body mass females $: \mathrm{r}_{\mathrm{s}}=-0.43, \mathrm{n}=21, \mathrm{P}=$
0.053; $\mathrm{SVL}_{\text {males }}: \mathrm{r}_{\mathrm{s}}=0.44, \mathrm{n}=14, \mathrm{P}=0.11 /$ body mass $\left._{\text {males }}: \mathrm{r}_{\mathrm{s}}=0.45, \mathrm{n}=14, \mathrm{P}=0.107\right)$, and non-reproductive seasons $\left(\mathrm{SVL}_{\text {females }}: \mathrm{r}_{\mathrm{s}}=-\right.$ $0.22, \mathrm{n}=23, \mathrm{P}=0.301 /$ body mass females $_{\mathrm{s}}: \mathrm{r}_{\mathrm{s}}=$ $0.25, \mathrm{n}=23, \mathrm{P}=0.238 ; \mathrm{SVL}_{\text {males }}: \mathrm{r}_{\mathrm{s}}=0.25, \mathrm{n}=$ $13, \mathrm{P}=0.405 /$ body mass males $: \mathrm{r}_{\mathrm{s}}=0.27, \mathrm{n}=$ $13, \mathrm{P}=0.362$ ).

Average home range size differed significantly between the percentages of sightings considered on the grid $(50,60,70,80$, 90 and $100 \%)$ for females in both seasons (RS: Kruskal-Wallis test; $\mathrm{H}_{5}=71.20, \mathrm{P}=0.0001$; NRS: Kruskal-Wallis test; $\mathrm{H}_{5}=98.15, \mathrm{P}=$ 0.0001 ), and for males in the same season (RS: Kruskal-Wallis test; $\mathrm{H}_{5}=62.63, \mathrm{P}=0.0001$; NRS: Kruskal-Wallis test; $\mathrm{H}_{5}=58.17, \mathrm{P}=$ $0.0001)$. Because sighting percentages between $50 \%$ and $60 \%$ for females, and between $50 \%$ and $70 \%$ for males were not significantly different in their home range sizes (post-hoc Mann-Whitney multiple comparison tests, $\mathrm{P}>$ 0.05 ; Table 2), $60 \%$ and $70 \%$ of sightings represented the female and male home ranges, respectively, in both seasons. Average home range size in each season was $20.6 \pm 9.4 \mathrm{~m}^{2}$ (RS) and $29.4 \pm 12.1 \mathrm{~m}^{2}$ (NRS) for females, and $34.4 \pm 11.3 \mathrm{~m}^{2}(\mathrm{RS})$ and $53.7 \pm 19.0 \mathrm{~m}^{2}$ (NRS) for males. According to these results, males have a larger mean home range size than females in both seasons (RS: Mann-Whitney U test, $\mathrm{Z}=-3.05, \mathrm{P}=0.002$; NRS: Mann-Whitney $\mathrm{U}$ test, $\mathrm{Z}=-3.83, \mathrm{P}=0.0001)$.

For the same specimens monitored over the eight months, the home range size of both females (RS: $17.0 \pm 6.5 \mathrm{~m}^{2}$; NRS: $27.0 \pm 10.0$ $\mathrm{m}^{2} ; \mathrm{n}=8$; Wilcoxon test, $\left.\mathrm{Z}=-2.20, \mathrm{P}=0.012\right)$ and males (RS: $32.7 \pm 12.2 \mathrm{~m}^{2}$; NRS: $55.7 \pm$ $20.1 \mathrm{~m}^{2} ; \mathrm{n}=11 ;$ Wilcoxon test, $\mathrm{Z}=-2.40, \mathrm{P}=$ $0.016)$ was larger in the non-reproductive season than in the reproductive season.

TABLE 1

Mean total range sizes $\left( \pm 1 \mathrm{SD}\right.$, range; $\mathrm{m}^{2}$ ) of adult female and male Tropidurus torquatus determined using the minimum convex polygon, during reproductive (RS) and non-reproductive (NRS) seasons. Sample sizes in parenthesis.

Tamaño promedio del dominio vital $\left( \pm 1 \mathrm{DE}\right.$, amplitud; $\left.\mathrm{m}^{2}\right)$ de hembras y machos adultos de Tropidurus torquatus determinado con el mínimo polígono convexo, durante las estaciones reproductiva (RS) y no reproductiva (NRS). Tamaño de muestra entre paréntesis.

\begin{tabular}{lcr}
\hline Season & Females & \multicolumn{1}{c}{ Males } \\
\hline RS & $37.0 \pm 13.713 .0-64.5(21)$ & $50.8 \pm 20.722 .5-94.0(14)$ \\
NRS & $58.9 \pm 21.825 .5-89.5(23)$ & $72.6 \pm 32.931 .5-137.5(13)$ \\
\hline
\end{tabular}


TABLE 2

Mean home range sizes $\left( \pm 1 \mathrm{SD} ; \mathrm{m}^{2}\right)$ of adult female and male Tropidurus torquatus determined using the harmonic mean method, according to percentage of sightings during reproductive (RS) and non-reproductive (NRS) seasons. Sample sizes in parenthesis.

Tamaño promedio de las áreas de vida $\left( \pm 1 \mathrm{DE} ; \mathrm{m}^{2}\right)$ de hembras y machos adultos de Tropidurus torquatus determinado con el método de la media armónica, según los porcentajes de localizaciones durante las estaciones reproductiva (RS) y no reproductiva (NRS). Tamaño de muestra entre paréntesis.

\begin{tabular}{|c|c|c|c|c|c|c|c|}
\hline \multirow[t]{2}{*}{ Season } & \multirow[t]{2}{*}{ Sex } & \multicolumn{6}{|c|}{ Mean home range sizes by percentage of lizard sightings } \\
\hline & & $50 \%$ & $60 \%$ & $70 \%$ & $80 \%$ & $90 \%$ & $100 \%$ \\
\hline \multirow[t]{2}{*}{$\mathrm{RS}$} & ㅇ (21) & $13.0 \pm 9.1$ & $20.6 \pm 9.4$ & $29.7 \pm 12.2$ & $38.9 \pm 17.1$ & $53.5 \pm 21.5$ & $84.2 \pm 31.4$ \\
\hline & $\sigma^{\prime}(14)$ & $16.3 \pm 7.1$ & $24.3 \pm 8.4$ & $34.4 \pm 11.3$ & $53.6 \pm 22.3$ & $73.1 \pm 26.7$ & $117.3 \pm 45.5$ \\
\hline \multirow[t]{2}{*}{ NRS } & \$ (23) & $19.5 \pm 8.0$ & $29.4 \pm 12.1$ & $40.4 \pm 13.1$ & $58.0 \pm 18.5$ & $78.4 \pm 27.2$ & $115.1 \pm 42.7$ \\
\hline & $\sigma^{2}(13)$ & $28.3 \pm 12.1$ & $38.1 \pm 15.3$ & $53.7 \pm 19.0$ & $70.9 \pm 20.2$ & $105.0 \pm 36.6$ & $152.3 \pm 65.3$ \\
\hline
\end{tabular}

\section{Microhabitat use}

The lizards were sighted mainly on rocks in both seasons (RS: $78.6 \%$; NRS: $70.4 \%$ ). However, from the reproductive to the nonreproductive season, they increased their use of microhabitats with colonizing vegetation at the outcrop edge, such as tree trunks (RS: $6.9 \%$; NRS: $13.7 \%$ ) and bromeliads (RS: $1.6 \%$; NRS: $3.7 \%$ ) (Fig. 2). During the reproductive season, males and females did not exhibit differences in microhabitat use (Males: $\mathrm{R}=$ $77.5 \%, \mathrm{BS}=10.6 \%, \mathrm{SV}=7.3 \%, \mathrm{~T}=0.7 \%$, $\mathrm{B}=4.0 \%$; Females: $\mathrm{R}=79.3 \%, \mathrm{BS}=9.7 \%$, $\mathrm{SV}=6.6 \%, \mathrm{~T}=2.2 \%, \mathrm{~B}=2.2 \%$; Chi-square, $\left.\chi^{2}=2.50, \mathrm{P}=0.644\right)$. In contrast, microhabitat use during the non-reproductive season differed significantly between sexes (Males: $\mathrm{R}=75.5$ $\%, \mathrm{BS}=4.2 \%, \mathrm{SV}=14.6 \%, \mathrm{~T}=2.1 \%, \mathrm{~B}=$ $3.6 \%$; Females: $\mathrm{R}=67.3 \%, \mathrm{BS}=4.4 \%, \mathrm{SV}=$ $13.2 \%, \mathrm{~T}=4.7 \%, \mathrm{~B}=10.4 \%$; Chi-square, $\chi^{2}$ $=10.47, \mathrm{P}=0.033)$.

\section{Activity patterns}

During the reproductive season, which comprised part of the rainy period, lizard activity followed a bimodal pattern with activity peaks at 09:00 and 14:00 h (Fig. 3A). Air temperature varied between the minimum average of $22.9 \pm 1.9{ }^{\circ} \mathrm{C}$ between 08:00 and 09:00 $\mathrm{h}$ and the maximum average of $29.0 \pm 2.7$ ${ }^{\circ} \mathrm{C}$ between 14:00 and 15:00 $\mathrm{h}$. In the nonreproductive season (part of the dry period), lizard activity followed a unimodal pattern with activity peak at 11:00 h (Fig. 3B). Air temperature varied between the minimum average of $18.4 \pm 2.7{ }^{\circ} \mathrm{C}$ between 08:00 and 09:00 $\mathrm{h}$, and the maximum average of $26.4 \pm$ $2.7^{\circ} \mathrm{C}$ between 13:00 and 14:00 h. There was a significant difference in activity patterns between both seasons (Kolmogorov-Smirnov, $\left.\mathrm{D}_{\max }=0.18, \mathrm{P}<0.001\right)$.

\section{DISCUSSION}

\section{Gender and season}

During the reproductive season, the ranges of adult male $T$. torquatus were significantly larger than those of females, not only in terms of general size (total range established by the MCP method), but also in area intensively used (home range established by the harmonic mean method). Males of many lizard species have range sizes twice as large as those of females, an important factor, especially during the reproductive period (Rose 1982, Frutos \& Belver 2007). In addition, male T. torquatus are territorial and polygynous (Rodrigues 1987, Bergallo \& Rocha 1994), and the establishment of ranges larger than those of females, in addition to including them in their range use, may also reflect the requirements of the polygynous mating system. The mean number of females included in the total range of males tended to be higher during the reproductive season, a finding that could increase the chance of males finding females. Furthermore, male reproductive success has been positively correlated with the number of females 
associated with a male's range (Ruby 1978, Rose 1982, Stamps 1983, Martins 1994, Haenel et al. 2003a). The tendency of an increased number of female ranges overlapped by male ranges during the reproductive season was also described for other species/subspecies, such as T. itambere Rodrigues, 1987 (Van Sluys 1997), Liolaemus lutzae Mertens, 1938 (Rocha 1999) and Sceloporus undulatus hyacinthinus (Green, 1818) (Haenel et al. 2003a).

Clobert et al. (1994) observed that sites with high quality resources are densely occupied by lizards to complete their life cycles. Our data suggest that this same pattern occurs, at least for females during the reproductive season, when the number of females associated with other female ranges was high, mainly in rock blocks that they used for oviposition. Van Sluys (1997) attributed high densities of female $T$. itambere during the breeding season to the fact that a smaller female home range size favors the sharing of spatial resources for nesting on rock outcrops. On the other hand, the small overlap that we found between male ranges during both seasons suggests that males use more exclusive areas. This space use pattern for males seems to be indirect evidence of their territorial behavior. We also found that most interactions between males (e.g., chases, bites) occur in the vicinity of females, providing further evidence that male home areas in $T$. torquatus reflect efforts to gain access to females.

The larger total and home range size of $T$. torquatus during the non-reproductive season, compared to those in the reproductive season, apparently results from the lizards' activity being concentrated in larger areas, including the rock outcrop-soil interface, to find food during periods of drought (Kolodiuk et al. 2009). Nevertheless, the male and female range sizes of T.torquatus found in the present study in general agree with those described for this species (Giaretta 1996), where males used larger areas than females did, and for other lizards of this genus (Van Sluys 1997) and trophic level (Rocha 1999).

\section{Microhabitat use}

Tropidurus torquatus is known to use varied types of microhabitats, characterizing it as a microhabitat-generalist (Rodrigues 1987). In our study site lizards were observed mainly on rock surfaces. In addition to functioning as perches and reproductive sites, rocks provide

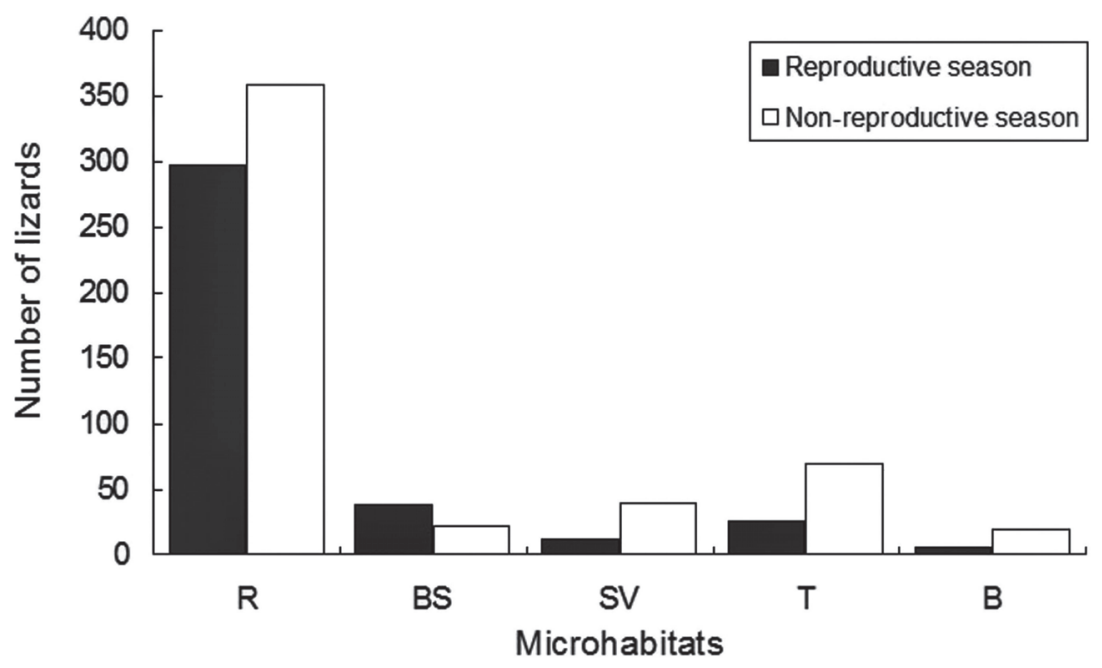

Fig. 2: Number of Tropidurus torquatus observed in different microhabitats during reproductive (378 lizards sighted) and non-reproductive (510 lizards sighted) seasons, in the state of Minas Gerais, southeastern Brazil. $\mathrm{R}=$ rocks; $\mathrm{BS}=$ bare sand; $\mathrm{SV}=$ sand with herbaceous-shrubby vegetation; $\mathrm{T}=$ trunks; $\mathrm{B}=$ bromeliads.

Número de Tropidurus torquatus observados en los diferentes microhábitats durante las estaciones reproductiva (378 lagartos avistados) y no reproductiva (510 lagartos avistados) en el estado de Minas Gerais, sudeste de Brasil. $\mathrm{R}=$ rocas; $\mathrm{BS}=$ arena desnuda; $\mathrm{SV}=$ arena con vegetación; $\mathrm{T}=$ troncos $; \mathrm{B}=$ bromélia . 
shelter and thermoregulation sites for lizards (Ribeiro et al. 2008). Rocks at different inclinations allowed lizards to actively select them according to time of day and their thermal demands. The preference for rock surfaces as thermoregulation sites was observed for other Brazilian congeners in different open habitats (Rocha \& Bergallo 1990, Vitt \& Carvalho 1995, Faria \& Araújo 2004, Van Sluys et al. 2004).

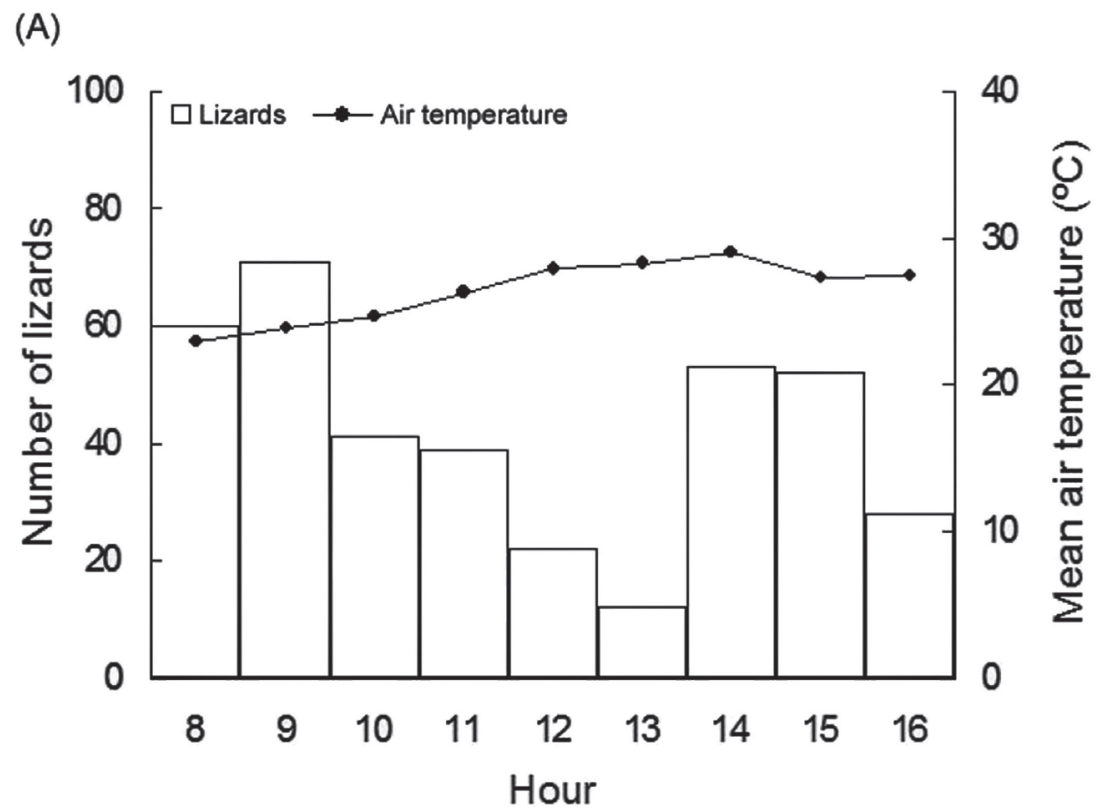

(B)

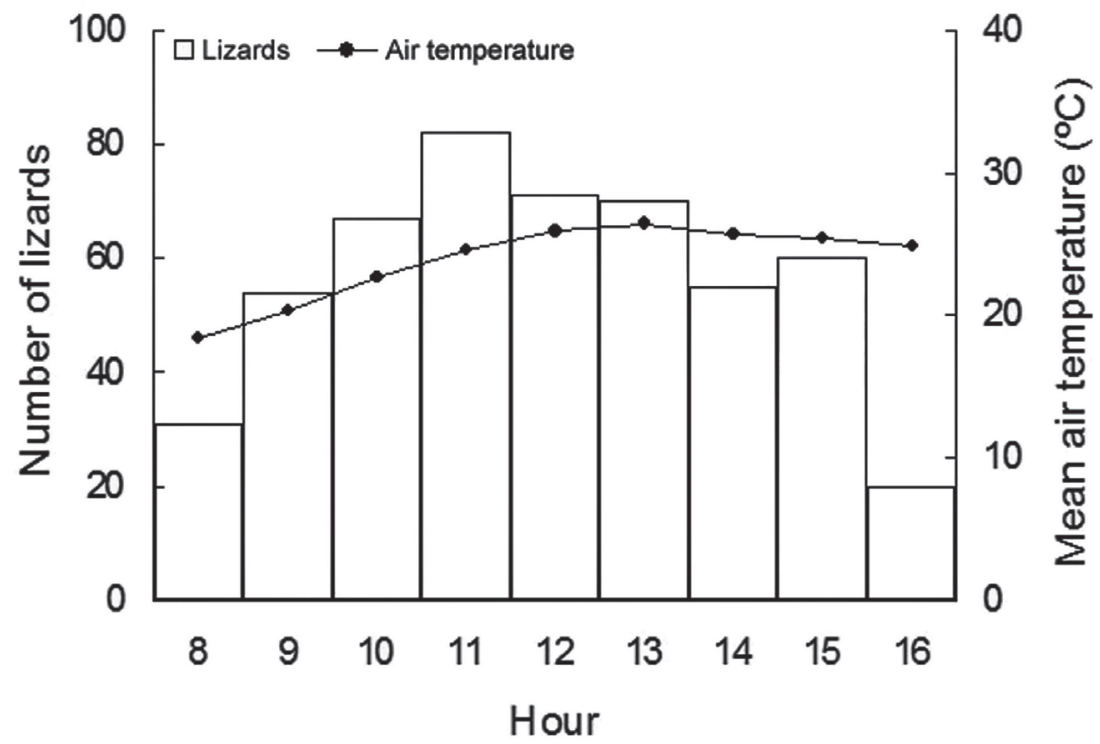

Fig. 3: Number of visible active Tropidurus torquatus and mean air temperature at hourly intervals, during reproductive (A: November 2004 to February 2005; 378 lizards sighted) and non-reproductive (B: from March to June 2005; 510 lizards sighted) seasons, in the state of Minas Gerais, southeastern Brazil.

Número de Tropidurus torquatus visibles activos y temperatura media del aire en intervalos de cada hora, durante las estaciones reproductiva (A: noviembre 2004 a febrero 2005; 378 lagartos avistados) y no reproductiva (B: marzo a junio 2005; 510 lagartos avistados) en el estado de Minas Gerais, sudeste de Brasil. 
Considering that the importance of microhabitats used by lizards in a habitat can change over time, owing to alterations in environmental pressures and animal needs, lizards may modify their range location (Clobert et al. 1994). Our results suggest that the spatial distribution of $T$. torquatus was characterized by changes in the temporal importance of their microhabitats. Thus, during the reproductive season, there was greater use of spatial resources in the central portion of the rock outcrop, formed basically by rock blocks containing crevices, where we observed oviposition. Microhabitats under rocks and crevices were identified as oviposition sites for $T$. torquatus (Rocha et al. 2002), and for the syntopic species T. semitaeniatus (Spix, 1825) and T. hispidus (Spix, 1825) (Vitt \& Goldberg 1983).

On the other hand, during the nonreproductive season, which spanned most of the dry period, the lizards were located more peripherally on the rock outcrop. At this time, lizards exhibited searching movements, increasing their opportunity to capture prey (e.g., beetles and butterflies; Gomides et al. 2006) away from rock surfaces by moving across tree trunks, branches, and bromeliad foliage. The assortment of microhabitats used by $T$. torquatus, such as those associated to the vegetation observed in our study, demonstrates their plasticity, a factor contributing to their survival in the environment (Teixeira \& Giovanelli 1999).

\section{Activity patterns}

Tropidurus torquatus exhibit a prolonged activity period, remaining active during almost all photophases of the photoperiod (Bergallo \& Rocha 1993, Teixeira-Filho et al. 1996). Nonetheless, the seasonal variation in activity patterns observed for $T$. torquatus at Toledos has also been observed for this species in coastal (Hatano et al. 2001) and insular (Rocha et al. 2002) habitats, as well as for T. itambere on a rock outcrop located within the Atlantic Forest Domain (Van Sluys 1992). Our results suggest that in the rainy season, higher midday temperatures reduce the lizards' activity, when individuals retreat to shady sites as an effective behavioral mechanism for thermal control. Conversely, in the dry season, milder temperatures enabled greater levels of activity from sunrise to sunset.
The lizards' activity pattern is associated to the particularities of each habitat such as topography, vegetation composition and availability of direct sunlight, conditions that allow heliophilous lizards to exploit the diurnal period in its entirety (Hatano et al. 2001). Despite the characteristics of the rock outcrop in our study area (e.g., central position, surrounded by tall mountain formations that prevent it from receiving direct sunlight after 17:00 $\mathrm{h}$, and the milder temperatures in the Zona da Mata region, southeastern Minas Gerais), the seasonal activity pattern of $T$. torquatus follows that described for other populations of this species, and congener species in sand-dune, inland or insular habitats.

\section{ACKNOWLEDGMENTS}

This study is part of the Master's dissertation of LB Ribeiro submitted as a requirement for obtaining the title of Master in Biological Sciences (Animal Behavior and Biology), Institute of Biological Sciences of the Federal University of Juiz de Fora (UFJF). We thank M Van Sluys, GR Colli, CAB Galdino for offering invaluable suggestions during the research, JA Silva and AF Beraldo for helping with data analysis, and two anonymous reviewers for their contributions towards improving the manuscript. This study was supported by a grant from Coordenação de Aperfeiçoamento de Pessoal de Nível Superior (CAPES) to LB Ribeiro. Research involving animals was in accord with the Ethical Principles of Animal Experimentation adopted by the Brazilian School of Animal Experimentation (COBEA), with approval of the Commission for Ethics in Animal Experimentation (CEEA) from the Research Rectory/UFJF (Protocol 010/2005CEEA), and under permission of IBAMA (Permit 261/05-NUFAS/MG and Process 02015.010660/05-88).

\section{LITERATURE CITED}

BERGALLO HG \& CFD ROCHA (1993) Activity patterns and body temperatures of two sympatric lizards (Tropidurus torquatus and Cnemidophorus ocellifer) with different foraging tactics in Southeastern Brazil. Amphibia-Reptilia 14: 312 315 . 
BERGALLO HG \& CFD ROCHA (1994) Spatial and trophic niche differentiation in two sympatric lizards (Tropidurus torquatus and Cnemidophorus ocellifer) with different foraging tactics. Australian Journal of Ecology 19: 72-75.

BROWN JL \& GH ORIANS (1970) Spacing patterns in mobile animals. Annual Review of Ecology and Systematics 1: 183-199.

CLOBERT J, M MASSOT, J LECOMTE, G SORCI, M DE FRAIPONT \& R BARBAULT (1994). Determinants of dispersal behavior: The common lizard as a case study. In: Vitt LJ \& ER Pianka (eds) Lizard ecology: Historical and experimental perspectives: 183-206. Princeton University Press, Princeton, New Jersey.

DAVIES NB (1991) Mating systems. In: Krebs JR \& NB Davies (eds) Behavioural ecology: 263-294. Blackwell Scientific Publications, Oxford, United Kingdom.

DE SOLLA SR, R BONDURIANSKY \& RJ BROOKS (1999) Eliminating autocorrelation reduces biological relevance of home range estimates. Journal of Animal Ecology 68: 221-234.

DIXON KR \& JA CHAPMAN (1980) Harmonic mean measure of animal activity areas. Ecology 61: 10401044.

FARIA RG \& AFB ARAÚJO (2004) Sintopy of two Tropidurus lizard species (Squamata: Tropiduridae) in a rocky cerrado habitat in central Brazil. Brazilian Journal of Biology 64: 775-786.

FRUTOS N \& LC BELVER (2007) Dominio vital de Liolaemus koslowskyi Etheridge, 1993 (Iguania: Liolaemini) en el noroeste de la provincia de $\mathrm{La}$ Rioja, Argentina. Cuadernos de Herpetología 21: 83-92.

GIARETTA AA (1996) Tropidurus torquatus. Home range. Herpetological Review 27: 80-81.

GOMIDES SC, AO SANTOS, LB RIBEIRO \& BM SOUSA (2006) Dieta de Tropidurus torquatus (Wied, 1820) (Squamata: Tropiduridae) em uma área de afloramento rochoso no município de Juiz de Fora, MG. Anais da Sociedade Brasileira para o Progresso da Ciência 58: 196-196.

HAENEL GJ, LC SMITH \& HB JOHN-ALDER (2003a). Home-range analysis in Sceloporus undulatus. II. A test of spatial relationships and reproductive success. Copeia 2003: 113-123.

HAENEL GJ, LC SMITH \& HB JOHN-ALDER (2003b) Home range analysis in Sceloporus undulatus (eastern fence lizard). I. Spacing patterns and the context of territorial behavior. Copeia 2003: 99112.

HATANO FH, D VRCIBRADIC, CAB GALDINO, M CUNHA-BARROS, CFD ROCHA \& M VAN SLUYS (2001) Thermal ecology and activity patterns of the lizard community of the restinga of Jurubatiba, Macaé, RJ. Revista Brasileira de Biologia 61: 287-294.

HODDER KH, RE KENWARD, SS WALLS \& RT CLARKE (1998) Estimating core ranges: A comparison of techniques using the common buzzard Buteo buteo. Journal of Raptor Research 2: 82-89.

KERR GD \& CM BULL (2006) Exclusive core areas in overlapping ranges of the sleepy lizard, Tiliqua rugosa. Behavioral Ecology 17: 380-391.

KOLODIUK MF, LB RIBEIRO \& EMX FREIRE (2009) The effects of seasonality on the foraging behavior of Tropidurus hispidus and Tropidurus semitaeniatus (Squamata, Tropiduridae) living in sympatry in the Caatinga of northeastern Brazil. Zoologia 26: 581-585.

LIMA SL \& LM DILL (1990) Behavioral decisions made under the risk of predation: $A$ review and prospectus. Canadian Journal of Zoology 68: 619640.

LINN I \& G KEY (1996) Use of space by the African striped ground squirrel Xerus erythropus. Mammal Review 1: 9-26.

LOEHLE C (1990) Home range: A fractal approach. Landscape Ecology 5: 39-52.

LOTT DF (1991) Intraspecific variation in the social systems of wild vertebrates. Cambridge University Press, Cambridge, United Kingdom. 233 pp.

MARTINS EP (1994) Phylogenetic perspectives on the evolution of lizard territoriality. In: Vitt LJ \& ER Pianka (eds) Lizard ecology: Historical and experimental perspectives: 117-144. Princeton University Press, Princeton, New Jersey.

NÚNEZZ H, PA MARQUET, RG MEDEL \& FM JAKSIC (1989) Niche relationships between two sympatric Liolaemus lizards in a fluctuating environment: The "lean" versus "feast" scenario. Journal of Herpetology 23: 22-28

PERRY G \& T GARLAND (2002) Lizard home ranges revisited: Effects of sex, body size, diet, habitat and phylogeny. Ecology 83: 1870-1885.

PINTO ACS, HC WIEDERHECKER \& GR COLLI (2005) Sexual dimorphism in the Neotropical lizard, Tropidurus torquatus (Squamata: Tropiduridae). Amphibia-Reptilia 26: 127-137.

PLANO DIRETOR/JF (2004) Clima de Juiz de Fora. Laboratório de Climatologia e Análise Ambiental, Departamento de Geociências da Universidade Federal de Juiz de Fora, Estação Climatológica Principal de Juiz de Fora, Minas Gerais, Brasil. URL: http://www.pjf.mg.gov.br/cidade/clima.php (accessed March 22, 2005).

RADDER RS, SK SAIDAPUR \& BA SHANBHAG (2005) Population density, microhabitat use and activity pattern of the Indian rock lizard, Psammophilus dorsalis (Agamidae). Current Science 89: 560-566.

RIBEIRO LB \& BM SOUSA (2006) Elastic hair bands: An effective marking technique for lizards in markrecapture studies. Herpetological Review 37: 434435.

RIBEIRO LB, SC GOMIDES, AO SANTOS \& BM SOUSA (2008) Thermoregulatory behavior of the saxicolous lizard, Tropidurus torquatus (Squamata: Tropiduridae), in a rocky outcrop in Minas Gerais, Brazil. Herpetological Conservation and Biology 3: 63-70.

ROCHA CFD (1999) Home range of the tropidurid lizard Liolaemus lutzae: Sexual and body size differences. Revista Brasileira de Biologia 59: 125-130.

ROCHA CFD \& HG BERGALLO (1990) Thermal biology and flight distance of Tropidurus oreadicus (Sauria, Iguanidae) in an area of Amzonian Brazil. Ethology Ecology \& Evolution 2: 263-268

ROCHA CFD, GF DUTRA, D VRCIBRADIC \& VA MENEZES (2002) The terrestrial reptile fauna of the Abrolhos Archipelago: Species list and ecological aspects. Brazilian Journal of Biology 62: 285-291.

RODRIGUES MT (1987) Sistemática, ecologia e zoogeografia dos Tropidurus do grupo torquatus ao Sul do Rio Amazonas (Sauria, Iguanidae). Arquivos de Zoologia do Estado de São Paulo 31: 105-230.

ROSE B (1982) Lizard home ranges: Methodology and functions. Journal of Herpetology 16: 253-269. 
RUBY DE (1978) Seasonal changes in territorial behavior of the iguanid lizard Sceloporus jarrovi. Copeia 1978: 430-438.

SHELDAHL LA \& EP MARTINS (2000) The territorial behavior of the western fence lizard, Sceloporus occidentalis. Herpetologica 56: 469-479.

SCHOENER TW (1977) Competition and the niche. In: Gans C \& DW Tinkle (eds) Biology of Reptilia: 35136. Academic Press, New York.

SIEGEL S (1975) Estatística não paramétrica para as ciências do comportamento. McGraw-Hill, São Paulo. 350 pp.

SPSS INC (2004) SPSS for Windows, Release 13.0. Chicago, Illinois.

STAMPS JA (1983) Sexual selection, sexual dimorphism, and territoriality. In: Huey RB, ER Pianka \& TW Schoener (eds) Lizard ecology: Studies of a model organism: 169-204. Harvard University Press, Cambridge, Massachusetts.

STONE PA \& TA BAIRD (2002) Estimating lizard home range: The Rose Model revisited. Journal of Herpetology 36: 427-436.

TEIXEIRA-FILHO P, CFD ROCHA \& S RIBAS (1996) Aspectos da ecologia termal de Tropidurus torquatus (Sauria: Tropiduridae) em uma área de restinga do Sudeste do Brasil. In: Pefaur JE (ed) Herpetologia Neotropical: 255-267. Consejo Publicaciones, Universidad de Los Andes, Merida, Venezuela.

TEIXEIRA RL \& M GIOVANELLI (1999) Ecologia de Tropidurus torquatus (Sauria: Tropiduridae) da restinga de Guriri, São Mateus, ES. Revista Brasileira de Biologia 59: 11-18.

VAN SLUYS M (1992) Aspectos da ecologia do lagarto Tropidurus itambere (Tropiduridae), em uma área do Sudeste do Brasil. Revista Brasileira de Biologia 52: 181-185.

VAN SLUYS M (1997) Home range of the saxicolous lizard Tropidurus itambere (Tropiduridae) in Southeastern Brazil. Copeia 1997: 623-628.

VAN SLUYS M, CFD ROCHA, D VRCIBRADIC, CAB GALDINO \& AF FONTES (2004) Diet, activity and microhabitat use of two syntopic Tropidurus species (Lacertilia: Tropiduridae) in Minas Gerais, Brazil. Journal of Herpetology 38: 606-611.

VITT LJ \& CM CARVALHO (1995) Niche partitioning in a tropical wet season: Lizards in the Lavrado area of northern Brazil. Copeia 1995: 305-329.

VITT LJ \& SR GOLDBERG (1983) Reproductive ecology of two tropical iguanid lizards: Tropidurus torquatus and Platynotus semitaeniatus. Copeia 1983: 131-141.

VITT LJ, JP CALDWELL, PA ZANI \& TA TITUS (1997) The role of habitat shift in the evolution of lizard morphology: Evidence from tropical Tropidurus. Proceedings of the National Academic of Sciences 94: 3828-3832.

VITT LJ, PA ZANI \& JP CALDWELL (1996) Behavioural ecology of Tropidurus hispidus on isolated rock outcrops in Amazonia. Journal of Tropical Ecology 12: $81-101$

WIEDERHECKER HC, ACS PINTO \& GR COLLI (2002) Reproductive ecology of Tropidurus torquatus (Squamata: Tropiduridae) in the highly seasonal Cerrado biome of Central Brazil. Journal of Herpetology 36: 82-91.

WONE B \& B BEAUCHAMP (2003) Movement, home range and activity patterns of the horned lizard, Phynosoma mcallii. Journal of Herpetology 37: 679-686.

ZAR JH (1999) Biostatistical analysis. Fourth edition. Prentice-Hall Inc., Upper Saddle River, New Jersey. $663 \mathrm{pp}$.

ZUG GR, LJ VITT \& JP CALDWELL (2001) Herpetology: An introductory biology of amphibians and reptiles. Second edition. Academic Press, California. 630 pp. 